Akpınar, O., \& Pektaş, E. K. (2019). Yavaş şehirler (Cittaslow) ve kentsel yaşam kalitesi üzerindeki etkileri: Seferihisar halkının algısı üzerine bir araștırma. KOCATEPEIIBF Dergisi, Haziran 2019, 21(1), 31-46.

\title{
YAVAŞ ŞEHİRLER (CITTASLOW) VE KENTSEL YAŞAM KALİTESİ ÜZERİNDEKİ ETKİLERİ: SEFERİHİSAR HALKININ ALGISI ÜZERİNE BİR ARAŞTIRMA1 OKAN AKPINAR ${ }^{2}$, ETHEM KADRI PEKTAŞ3
}

ÖZ

İkinci Dünya Savaşı'ndan sonra hem dünya nüfusunun hızlı bir şekilde artması hem de teknoloji ve sanayileşme alanında yaşanan gelişmeler kentlere doğru göçün hızlanmasına neden olmuştur. İletişim ve ulaşım alanındaki teknolojik gelişmelerin, zaman ve mekân sınırını ortadan kaldırması ile gerçekleșen küreselleşme olgusu da üretim ve tüketimde hız kavramının gelişmesine zemin hazırlamıștır. Așırı kentleşme ve küreselleşmenin doğayı göz ardı eden yaklaşımlarına karşılık olarak; çevresel değerlerin gelecek nesillere aktarılmasını, yerel ekonominin ve kültürel varlıkların ön plana çıkarılmasını ve kentsel yaşam kalitesinin artırılmasını amaçlayan Yavaş Şehir (Cittaslow) Hareketi ortaya çlkmıştır. Bu çalışmada Türkiye ve dünyanın farklı bölgelerinde, farklı kişi ve kurumlar tarafından yürütülen bilimsel çalıșmalar sonucu geliştirilen kentsel yaşam kalitesi kriterlerinden yararlanarak, Seferihisar'ın Yavaș Şehir Birliği'ne üyeliğinin kentsel yaşam kalitesi üzerindeki etkilerini ölçmeye yardımcı olacak bir anket çalışması gerçekleştirilmiştir. Elde edilen bulgulara göre; fiziksel, ekonomik ve sosyal göstergeler dâhilinde altyapı, gelir düzeyi, nüfus artıșı ve diğer bazı konularda Seferihisar halkının genellikle olumsuz görüșlere sahip olduğu anlașılmıștır. Bu saptamadan hareketle çalışmanın sonunda; kentte altyapı ve üstyapı çalışmalarının hızlandırılması, ekonomik anlamda yerli üreticiye teşvik politikalarının uygulanması, belirli planlamalar ekseninde nüfus artışının kontrol altına alınması vb. çeşitli öneriler geliştirilmiştir.

Anahtar Kelimeler: Sürdürülebilirlik, Sürdürülebilir Gelişme, Yavaş Şehirler (Cittaslow), Kentsel Yaşam Kalitesi, Seferihisar

JEL Kodları: I38, Z18

\section{SLOW CITIES (CITTASLOW) AND THE EFFECTS ON URBAN LIVING QUALITY: A SURVEY ON THE PERCEPTION OF THE PEOPLE OF SEFERIHISAR}

\begin{abstract}
After the Second World War the developments in both technology and increasing world population and industrialization has led to the acceleration of migration to the cities. The phenomenon of globalization, which has been realized by eliminating the time and space boundary in the technological developments in communication and transportation, has also provided the basis for the development of the concept of speed in production and consumption. The Slow City (Cittaslow) Movement, which aims to transfer the environmental values to future generations, to bring local economy and cultural assets to the forefront and to improve the quality of urban life, has emerged against the approaches of excessive urbanization and globalization which ignore nature. In this study, a survey study was conducted to measure the impacts of the membership of the Seferihisar to the Slow City Union on urban quality of life by benefiting from urban quality of life criteria developed by different people and organizations in Turkey and the world's different regions. According to the datum; Seferihisar people have negative views on physical, economic and social indicators, infrastructure, income level, population growth and some other issues. Based on this determination, several recommendations were developed like acceleration of infrastructure and superstructure works in the city, implementation of incentive policies in the economic sense to the local producers, control of population growth in the axis of certain plans at the end of the study.
\end{abstract}

Keywords: Sustainability, Sustainable Urbanization, Slow Cities (Cittaslow), Urban Living Quality, Seferihisar

JEL Codes: I38, Z18

\footnotetext{
${ }^{1}$ Bu araștırma 2. yazarın danıșmanlığında 1. yazar tarafından hazırlanan yüksek lisans tezinden üretilmiștir.

2 Doktora Öğrencisi, Trakya Üniversitesi, okanakpinar@trakya.edu.tr - ORCID: 0000-0001-9629-1786

3 Prof.Dr., Afyon Kocatepe Üniversitesi, pektas@aku.edu.tr - ORCID: 0000-0002-8157-8861
} 


\section{GíRiş}

Tarihsel süreç içinde, insanların farklı amaçlar etrafında oluşturdukları ve yerleştikleri çok sayıda kent, endüstrileşme süreci ile birlikte hızlı bir değişim ve dönüşüm sürecine girmiş, özellikle gelişmekte olan ülkelerde zamanla yoğun göç alan ve kaynakların savurganca kullanıldığı mekânlar haline dönüşmüştür. 1980'li yıllarda hız kazanan küreselleşme süreci ile de üretim ve tüketimde yaşanan hızlı artış, kültürel tek tipleşme, yerel ekonomi ve yerel değerlerin arka planda kalması gibi sorunlar, kentlerin sosyo-kültürel ve ekonomik yönden de sürdürülemez hale gelmesine sebep olmuştur. Doğal kaynakların savurganca kullanılmasının önüne geçilerek gelecek kuşaklara sağlıklı bir şekilde aktarılmasını, yerel ekonominin geliştirilmesini, tarihi ve kültürel değerlerin korunmasını amaçlayan bir düşünce ürünü olarak; kentlerde yaşayan halkın çevresini, kültürünü ve kentsel kimliğini koruyarak günlük yașamını belirli bir kalite içerisinde devam ettirmesini sağlayacak biçimde, modern kentlere tepki ve sürdürülebilir kentleşme yaklaşımlarına örnek mahiyette "Yavaş Şehir (Cittaslow)" hareketi ortaya çıkmıştır.

Bu çalışma sürdürülebilirlik ve sürdürülebilir gelişme kavramlarını yavaş şehir hareketi ilke ve kriterleriyle birlikte yorumlayarak, yavaş şehir hareketinin kentleri ekonomik, sosyo-kültürel ve çevresel boyutta sürdürülebilir kılma yönündeki etkilerini ortaya koyma amacı gütmektedir. Çalışmada ayrıca yavaş şehirler ve kentsel yaşam kalitesi ilişkisinde, Türkiye'nin yavaş şehir başkenti olan Seferihisar'da, yavaş şehir hareketinin kentsel yaşam kalitesi üzerindeki etkilerinin bölge halkının algısı boyutuyla incelenmesi ve onların memnuniyet seviyelerinin ölçülmesi amaçlanmaktadır. Çalışma kapsamında ilk olarak sürdürülebilir gelişme kavramı ele alınarak sürdürülebilir gelişme düşüncesine örnek olarak yavaş şehir hareketi ve kentsel yaşam kalitesi ilișkisi incelenmekte ve yavaş şehir hareketinin Seferihisar'da yerel halkın kentsel yaşam kalitesine etkilerini belirleme amacına yönelik bir anket çalışması sonucu elde edilen bulgular analiz edilerek yorumlanmakta ve çeşitli öneriler geliştirilmektedir.

\section{SÜRDÜRÜLEBILIIR GELİŞME VE YAVAŞ ŞEHIRLER}

İkinci Dünya Savaşı́ndan sonra devletler, kalkınmada temel araç olarak gördükleri sanayileşmeye ciddi derecede önem vermişlerdir. Sanayileşme ile birlikte daha fazla mal ve hizmet anlayışı ile kalkınma standartlarının yükseltilmesi amacı sınırsız ve plansız bir tüketime neden olmakta ve devam eden bu tüketim de çevre ve kaynakların gelecek kuşaklara aktarılması konusunda önemli ölçüde tehlike oluşturmaktadır (Tıraş, 2012:58-59). Sanayileșmenin yanında kırsal yerleşimlerden kentlere doğru yoğun göç ile meydana gelen hızlı kentleşme de her açıdan aşırı bir tüketim sorununu ortaya çıkarmaktadır. Ekonomi bakımından yaşanan gelişmeler çevreyi ve kaynakları göz ardı eden bir anlayıș ile süregelmiştir. Ancak hem çevre hem de kaynaklar bakımından yenilenemez hale gelen dünyada bu kaynakları gelecek kuşaklara aktarmayı amaçlayan ve doğadaki diğer canlıların da yaşam hakkının olduğunu gözeten şekilde sürdürülebilirlik anlayışı çerçevesinde bir değişim süreci başlamıştır.

Sürdürülebilirlik, çevre değerlerinin ve doğal kaynakların savurganlığa yol açmayacak biçimde akılcı yöntemlerle bugünkü ve gelecek kuşakların hak ve yararları da göz önünde bulundurularak kullanılması ilkesinden hareketle, ekonomik gelişmenin sağlanmasını amaçlayan dünya görüşü olarak tanımlanmıştır (Keleş, 1998:112). Sürdürülebilir gelişme ise, kentleşme süreci boyunca insanların temel ihtiyaçlarını karşılarken çevresel kirliliği en aza indirmesi ve kaynakları en etkili ve tasarruflu bir şekilde gelecek kuşakları ve diğer bitki ve hayvan türlerini de göz ardı etmeyecek şekilde kullanarak kentin yaşanılabilir bir bölge olarak gelişmesi olarak tanımlanmaktadır (Tunçer, 2016:1273).

Sürdürülebilir gelişmenin amacı, yerleşimin olduğu bölgelerde, yaşam kalitesinin artırılması bağlamında insan ihtiyaçlarının, çevresel boyutun da dikkate alınarak karşılanmasını sağlamaktır. Bu ihtiyaçların karşılanması adına gerekli unsurlar ise, kentlerde kurumsal ve düzenleyici bir yönetim ve planlama anlayışının oluşturulmasıdır (Tosun, 2017:171).

Bir kentin sürdürülebilir olarak gelişmesindeki temel hedefler şöyle sıralanmaktadır (Tosun, 2013:107; Keskin, 2010:24-25):

- Yaşam kalitesi istikrarının sağlanması ve yoksulluğun engellenmesi,

- Doğal kaynaklar ve biyolojik çeşitliliğin korunması ile gelecek kuşakların bu haklardan mahrum birakılmamasi,

- Yenilenebilir enerji kaynaklarının kullanılmasının teşvik edilmesi ile tükenebilir kaynaklar üzerindeki baskı ve israfın önüne geçilmesi,

- Planlı bir kentleșme anlayışının oluşturulması ile arazi kullanımında verimliliğin sağlanması,

- Hava, su ve toprak kirliliğinin önlenmesi,

- Atık yönetiminde geri dönüşüm anlayışının yaygınlaştırılması,

- Kontrollü nüfus artışının sağlanması ve kendi kendine yetebilen kentlerin oluşturulması, 
- Toplumun sürdürülebilirlik konusunda bilinçlendirilmesi ve katılımının sağlanması,

- Sürdürülebilirliği temel alan teknolojilerin geliștirilmesidir.

Bu hedefler doğrultusunda sürdürülebilir olarak gelişen kentler ekonomik açıdan, daha az enerji kullanımı sağlayan, planlı ve kontrollü bir kalkınma ve kentleşmeye önem gösteren, geri dönüşümün yaygın olduğu ve çevreye duyarlı üretimin yapıldığı kentlerdir. Çevresel açıdan, yenilenebilir enerji kaynaklarının kullanıldığı, doğayı ve kaynakları göz ardı etmeyen sağlıklı bir çevre anlayışının geliştirildiği, çevresel bir planlama politikasının olușturulduğu, hava, su ve toprak kirliliğinin en aza indirildiği kentlerdir. Kültürel ve yönetimsel açıdan, bireyler arası iletişimin güçlü olduğu, işbölümünün yerleştiği, sınıflar arası eşitsizliğin önüne geçildiği, yaşam standardı kalitesinin sağlandığı, toplumun etkin katılımının gerçekleştiği, eğitimde sürdürülebilirlik bilincinin aktarıldığı, halka yakın ve kenti benimseyen yönetimlerin oluşturulduğu kentlerdir (Altuntaş, 2012:144-145).

\subsection{Küreselleşmeye Bir Tepki Olarak Yavaş Şehir Hareketi}

Sanayileşme ve yaşanan göçün yanı sıra gelişen teknolojinin dünyayı küçük bir köy haline getirmesi, küreselleşme olgusunu ortaya çıkarmıştır. Küreselleşme bir taraftan beraberinde olumlu etkiler getirirken, diğer taraftan da hızlı ve karşı koyulamaz bir tüketim durumuyla, çevresel ve kaynaksal sürdürülebilirliğin göz ardı edilmesi, özgünlük kavramının ve yerel değerlerin zarar görmesi gibi olumsuz etkilere de neden olmaktadır. Bu vesile ile küreselleşmenin zarar verici unsurlarına karşı bünyesinde yerel değerleri barındıran, çevresel, ekonomik ve sosyal olarak sürdürülebilirliği ön plana çıkaran kentlerin oluşturduğu bir sürdürülebilir yerel kalkınma olgusu, yavaş şehir (cittaslow) hareketi ortaya çıkmıştır (Yalçın, A. ve Yalçın, S., 2013:40).

Bir kentin kendine özgü gelenek ve kültürleri, yerel ürünleri, yerel yemekleri ve yerel zanaatları o kenti diğer kentlerden farklı kılan özgün kimliğidir. Küreselleşme ile birlikte kentlerin ekonomik kalkınma amacı ile girdiği rekabet ortamında, yoğun göç ile beraber oluşan hızlı nüfus artışı ve hızlı yapılaşma gibi olumsuzluklar neticesinde kentlerin yerel ve geleneksel değerleri yok olma boyutuna gelmiştir. Bu durum da kentlerde hem sürdürülebilirliğin hem de kentsel yaşam kalitesinin gerilemesine neden olmuștur (Deniz, 2017:1403). Küreselleşme ile kentlerin yerel kimliklerinin yok olmasının, kentte yaşayanların günlük yaşamlarının sıradanlaşmasının ve kaynakların savurganca kullanılmasının önüne geçilmesi adına 1999 yllında dört küçük İtalyan kentinin (Greve in Chianti, Positano, Bra ve Orvieto) belediye başkanları ile Slow Food (Yavaş Yemek) hareketi kurucusu Carlo Petrini tarafından yavaş yemek hareketinin kentsel boyutu olan ve İtalyanca "citta" (şehir) ile İngilizce "slow" (yavaş) kelimelerinden oluşan Yavaş Şehir (Cittaslow) Birliği kurulmuștur (Sezgin ve Ünüvar, 2011:127-128).

Yavaş şehirler, hayatın tadına varılacak hızda yaşanmasından hareketle, insanlar arası iletişimi, sosyalliği, geleneksel ürünlerin ön plana çıkarılmasını ve sürdürülebilir bir kentleşme anlayışı ile de çevrenin korunmasını, kirliliğin önlenmesini ve yenilenebilir enerji kaynaklarının teşvik edilmesini sağlayan bir kent hedefini benimsemektedir (www.cittaslowturkiye.org, E.T. 07.10.2018).

Yavaş şehir hareketi kendine logo olarak turuncu renkte, üzerinde tarihi binalar ile günümüzün binalarının olduğu bir salyangoz figürünü seçmiştir. Tarihi binalar ile kültürel değer ve miraslar ifade edilirken, günümüz binaları modern kentleri ifade etmektedir. Binaların üzerinde bulunduğu salyangoz ise Amerikan tarzı hayatın getirdiği hız kavramına karşı zamanın değerinin bilindiği ve hayatın tadına varılacak bir yavaşlıkta ilerlediği anlamına gelmektedir (Özgenç, 2012:112). Salyangoz, evini sırtında taşıyarak ulaşmak istediği yere acele etmeden, yavaş felsefesine uygun bir şekilde varmaktadır. Bu kapsamda düşünmeyi ve ağırbaşlılığı ön plana çıkaran yavaş hareketi bir akıl ve erdem ürünüdür (Keskin, 2012:90).

Şekil 1: Cittaslow Logo ve Sloganı

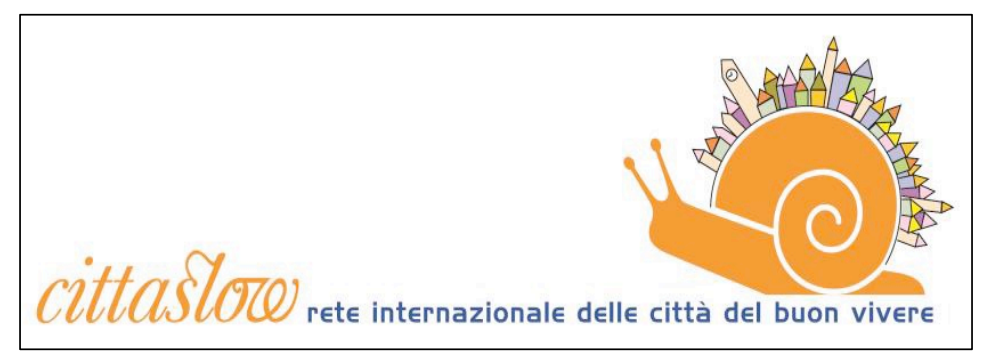

Kaynak: Cittaslow International Charter, 2017:28

Başta Yavaş Şehir Tüzüğü ve diğer tanımlar dikkate alınıp yavaş şehrin ne anlama geldiği ve neden tercih edildiği soruları sorulduğunda yavaş șehirlere ilişkin olarak genellikle şu nitelendirmeler yapılmaktadır (Deniz, 2017:1406; Olgun, 2016:20; Sezgin ve Ünüvar, 2011:135; Cittaslow International Charter, 2017): 
- Önüne geçilemez tüketim algısı ile beraber oluşan hızlı yașamın aksine insanların huzurlu olduğu ve aynı zamanda saat baskısından kurtulup ruhlarını da doyurabildikleri, yaşamak için yeterli zamanın oluşturulduğu kentlerdir.

- İnsanların birbirleri ile rahatça iletişim kurup sosyalleşebildikleri kentlerdir.

- Yerel-kültürel değerler ve ürünlerin ön plana çıkarılması ile hem küreselleşmenin dayattığı sıradanlaşmanın engellendiği hem de yerel pazarlar sayesinde ekonomik kalkınmanın gerçekleștiği kentlerdir.

- Geleneksel değerlerin korunması ile kent kimliğinin yaşatılmasını hedefleyen kentlerdir.

- Kentin tarihi ve kültürel mirasını iyileștiren, geliștiren ve koruyan kentlerdir.

- Çevre ve kaynakların korunup, bu kaynaklar üzerinde gelecek kuşakların da haklarının olduğunu göz ardı etmeyen ve gelecek kuşaklara miras bırakmak amacı ile sürdürülebilirliğin sağlanmasına katkıda bulunan kentlerdir.

- Çevreye uyumlu kentsel planlama ile çevre-şehir birlikteliğinin sağlandığı ve bu sayede kentleşme kalitesinin arttığı kentlerdir.

- Görüntü ve gürültü kirliliği ile birlikte hava, su, toprak kirliliğinin de engellendiği kentlerdir.

- Çevreye zarar vermeyen teknolojik gelişmeler ve yerel ekonominin sürdürülebilirliğine katkıda bulunarak gelir dağılımındaki eşitsizlikleri engelleyen ve bu sayede halkın kentsel yaşam kalitesini artıran kentlerdir (Yurtseven, Kaya ve Harman, 2010:40).

- Altyapı sorunları olmayan, yaya ve bisiklet yollarının daha fazla tasarlandığı ve toplu taşımanın teşvik edildiği kentlerdir.

- Yenilenebilir enerji kaynaklarının kullanıldı̆̆ı ve enerji tasarrufunun sağlandığı kentlerdir.

- Yavaş yemek hareketi öncülüğünde üretimin tamamen ekolojik yollarla yapıldığı ve sağlıklı gıdaların yetiştirildiği kentlerdir.

\subsection{Yavaş Şehirler ve Üyelik Kriterleri}

Yavaş şehir hareketi, çıkış noktası olan ve Yavaş Şehir Birliği'ne en çok üye kent bulunduran İtalya sınırları dâhilinde kalmayarak dünyanın pek çok ülkesinde yaygınlık kazanmıştır. Türkiye'de ise 2009 yılında İzmir'in bir ilçesi olan Seferihisar'ın üyeliğinden sonra yaygınlık kazanan yavaş șehir hareketi, 2019 yılı itibarıyla genişlemeye devam etmektedir.

Yavaş şehir hareketinin 2019 yllı itibarıyla dünyada 30 ülkede, 252 kentte üyesi bulunmaktadır. Türkiye'de yavaş şehir hareketine bakıldığında ise, 2009 yılında İzmir'in Seferihisar ilçesinin üyeliği ile başlayan yavaş şehir hareketi, sürdürülebilir şehirleri temel alması bakımından diğer kentler tarafından da dikkate alınmış ve 2019 yılı itibarıyla Yavaş Şehir Birliği'ne 15 kent üye olmuştur. Türkiye'nin ilk yavaş şehri olan Seferihisar'ın (2009) ardından Akyaka (2011), Gökçeada (2011), Taraklı (2011), Yenipazar (2011), Yalvaç (2012), Vize (2012), Perşembe (2012), Halfeti (2013), Şavşat (2015), Uzundere (2016), Eğirdir (2017), Gerze (2017), Göynük (2017) ve son olarak da 2018 yllının Mart ayında Mudurnu Yavaş Şehir Birliği'ne katılmıştır (www.cittaslowturkiye.org, E.T. 09.10.2018).

Yavaş şehir üyelik kriterleri: "çevre ve enerji politikaları", "altyapı politikaları", "kentsel yaşam kalitesi politikaları", "tarımsal, turistik, esnaf ve sanatkârlara yönelik politikalar", "misafirperverlik, farkındalık ve eğitim politikaları", "sosyal uyum politikaları" ve "ortaklıklar" olmak üzere 7 ana başlık altında toplanmaktadır. Söz konusu politika kriterleri kısaca şöyle açıklanabilir (Cittaslow International Charter, 2017:25-27):

Çevre ve enerji politikaları kriterleri, hava, su ve toprak kirliliğinin önlenmesi, kentsel katı atıklar ile endüstriyel ve evsel atıkların geri dönüşümü, çevreye zarar vermeyen yenilenebilir enerji kaynakları ile enerji tasarrufunun sağlanması, görüntü ve gürültü kirliliğinin önüne geçilmesi ile biyoçeşitliliğin korunması ilkeleri üzerinde durmaktadır.

Altyapı politikaları kriterlerinde temel alınan faaliyetler, bisiklet ve yaya yollarının artıılması, toplu taşıma araçlarının etkinliği ile çevreye duyarlı ulaşım sistemlerinin geliştirilmesi, engelli bireylere yönelik kent politikalarının benimsenmesi, kent merkezlerinde rekreasyon alanlarının artırılması ve tarihi mirasın korunmasıdır.

Kentsel yaşam kalitesi politikası kriterleri genel olarak, küreselleșen dünyada șehrin yerel ekonomisinin, tarihi ve kültürel değerlerinin korunması ve iyileștirilmesi, yeşil alanların artırılması, etkin internet ağı ile halka daha iyi ve hızlı hizmet sunulması, çevresel sürdürülebilirliği hedef alan biyomimarinin geliştirilmesi, görüntü kirliliği, gürültü kirliliği ve çevre kirliliği konusunda cezalandırma işlemlerinin yapılması, sürdürülebilir kentleșme planlarının oluşturulması ve teşvik edilmesi ile yerel zanaat ve lezzetler için pazar alanlarının kurulması gibi kriterlerden oluşmaktadır. 
Tarımsal, turistik, esnaf ve sanat politikaları kriterleri olarak, tarımda kimyasal gübrenin kullanılmadığı, enerji ve su tasarrufunun sağlandığı agroekolojinin geliştirilmesi, yerel değerleri yaşatan esnaf ve zanaatların korunması, kırsal bölgelerde yaşayan insanlara etkin hizmet sunulması, iyi-temiz-sağlıklı gıda anlayışına uygun yerel ve organik ürünlerin teşvik edilmesi, kente gelen ziyaretçiler için otellerdeki yatak kapasitelerinin artırılması ve genetiği değiştirilmiş ürünlerin yasaklaması görülmektedir.

Misafirperverlik, farkındalık ve eğitim politikaları kriterlerinde, kente gelen ziyaretçilere iyi bir karșılama ve tanıtımın gerçekleștirilmesi, kent ile ilgili alınacak kararlarda halkın etkin katılımının sağlanması, kentte yaşayanların yavaş şehir hareketi hakkında bilgilendirilmesi ve yavaş şehir hareketi ile ilgili projelerin desteklenmesi ön plana çıkmaktadır.

Sosyal dayanışma politikaları kriterinde, ırkçılık ve ayrımcılı̆̆ın engellenmesi, birlik ve hoşgörü anlayışının geliştirilmesi, engelli bireylere yönelik kent planlamalarının gerçekleștirilmesi, sivil toplum kuruluşları ve derneklerin etkin şekilde çalışmalarının teşvik edilmesi ve konut politikalarında yeterliliğin sağlanması ilkeleri yer almaktadır.

Son olarak ortaklıklar üzerine kriterlerde ise, yavaş yemek hareketine destek vermek ve yavaş şehir felsefesinin yaygınlaşması adına iş birliği yapmak ilkeleri ön plana çıkmaktadır.

Yavaş Şehir Tüzüğü'nde yer alan çevresel politikalar, ulaşım ve altyapı politikaları, kentsel yaşam kalitesini artırmaya yönelik politikalar, yerel değerleri ön plana çıkaran politikalar ile bölgenin tarihi ve kültürel mirasını korumaya yönelik politikalar çerçevesinde yavaş șehir amaç ve kriterlerinin sürdürülebilir gelişme hedefleri ile uyumlu ve kentsel yaşam kalitesi bağlamında halkın memnuniyet derecesini yükseltmeye yönelik politikalar olduğu söylenebilir.

\section{KENTSEL YAŞAM KALITTESI VE YAVAŞ ŞEHIRLER}

1950'lerden itibaren dünya nüfusunun artmasının bir sonucu olarak kentleşmenin de hızlanarak küresel ölçekte bir sorun haline gelmesiyle beraber, kentlerdeki yaşam kalitesi kavramı da küresel boyutta önem kazanmaya başlamış ve dünya nüfusunun büyük bölümünün kentlerde yaşaması neticesinde, kent ve yaşam kalitesi kavramı bir arada ele alınmaya başlamıştır (Yıldız, 2007).

Sanayi devrimi ve gelişen teknoloji ile beraber hızlanan kentleşme sonucu göz ardı edilen çevre ve kaynakların gelecek nesillerin de yararlanabileceği şekilde kullanılması amacıyla uluslararası düzeyde çalışmalar başlatılmış ve bu çalışmalar neticesinde sürdürülebilirlik ve yaşanabilirlik olgusu ile çevrenin ve kaynakların korunması ve kentsel yaşam kalitesinin sağlanması amaçlanmıştır (Ekşioğlu, 2011:26). Sürdürülebilirlik, günün ihtiyaçlarını gelecek kuşakların çevre ve kaynaklar üzerindeki haklarını göz ardı etmeden karşılamaktır. Yaşanabilirlik ise, bir kentte yaşayan halkın hoşnutluk ve memnuniyet seviyesinin yükseltilebilmesi için kentin gerçekleştirmesi gereken ölçütler olarak tanımlanmaktadır. Sürdürülebilirlik ve yaşanabilirlik ilkelerinin bir arada sağlanması ile halkın memnuniyet seviyesinde ve doğal olarak da kentsel yaşam kalitesinde bir artış meydana gelecektir (Ulusal Rapor ve Eylem Planı, 1996:76).

Kentsel yaşam kalitesi dar anlamda ekonomik, sosyal ve kültürel bağlamda kent olarak kabul edilen bir bölgede ulaşım, altyapı, barınma ve çevre unsurları gibi koşulların sınırlarının belirli düzeylerin üzerinde olmasıdır. Geniş anlamda ise, kentin sağladığı hizmet ve imkânlardan bireylerin eșit șekilde yararlanması, kentte düzenlenen tüm sosyal ve kültürel etkinliklere katılabilmesi ve siyasi olarak kent ile ilgili karar alma süreçlerinde aktif rol oynayabilmesi gibi toplumsal, kültürel ve siyasal süreçleri içerir (Kabadayı, 2006).

2019 yılı Mart ayı itibarıyla dünya nüfusunun yarısından fazlası (\%55.3) kentlerde yaşamaktadır (www.worldometers.info, E.T. 11.03.2019). Ancak kentlerde yaşayan bu nüfusun belirli kısmı temel gereksinimlerin karş̧lanamadığı ve plansız yapılaşmanın yaygın olduğu gecekondu bölgelerinde yaşamaktadır. Bu durumdan hareketle kentsel yaşam kalitesi kavramı bu bölgelerde yaşayan insanların da daha iyi yaşam standartlarına ulaşması bakımından önem kazanmaktadır. Ayrıca kentsel yaşam kalitesi, küreselleşme ile beraber büyük şirketlerin kentlerde yatırım fırsatı oluşturması ve yeni nüfusları kentlere çekmesi ile ekonomik kalkınmayı sağlaması bakımından kentlerin reklam ve tanıtımında önemli bir yere sahiptir. Kentsel yaşam kalitesi standartlarında yaşanacak düşüklük halkın o kentten ayrılmasına ve kentin ekonomik olarak sürdürülebilirliğinin zarar görmesine neden olacaktır (Yavuzçehre ve Torlak, 2006:186187).

Sanayileșmenin pek olmadığı, teknolojinin çevresel kaynaklara zarar vermeden halkın ihtiyaçlarını kolaylaştıracak şekilde kullanıldı̆̆ı, yerel ve kültürel değerlerin korunduğu yavaş şehirler, yaşamın karmaşık koşuşturmacasından uzak, çevre ve kaynakların gelecek kuşaklara aktarılabilecek şekilde kullanıldığı, planlı ve görsel açıdan etkin mimari yapılar ile sürdürülebilirliği ve yaşanabilirliği sağlayan kentlerdir. Bu bakımdan büyük șehirler ile kıyaslandığında daha iyi kentsel yaşam kalitesi ölçeğinde bir alternatif olarak uluslararası düzeyde olușturulan yavaş şehirleri büyük şehirlerden ayıran temel farklılık 
sürdürülebilirlik ve yaşanabilirlik açısından yerel halkın kentsel yaşam kalitesinin devamlılığını sağlamaktır (Coşar, 2013:57).

Bu bilgilerden hareketle yavaş şehir amaç ve kriterlerinin ekonomik, çevresel, sosyal sürdürülebilirlik ve yaşanabilirlik ile uyumlu olduğu ve gerçekleștirilmesi gereken bu amaç ve ilkeler ile kentte yaşayan insanların kentsel yaşam kalitesinin artırılmasına yönelik politikalar yürütüldüğü görülmektedir (Keskin, 2010:52).

\subsection{Kentsel Yaşam Kalitesi Göstergeleri}

Bir kentte ölçülen yaşam kalitesi seviyesinin doğru ve güvenilir bir şekilde belirlenmesinde göstergeler büyük önem taşımaktadır. 20-25 yıl aralığında yaşam kalitesini ölçmek adına yapılan çalışmalar ışığında genel olarak kabul edilebilecek belirli kentsel yaşam kalitesi göstergeleri oluşturulmuştur. Bu göstergeler şu şekilde sıralanmaktadır (Marans, 2007): İklim koşulları, nüfus yoğunluğu, kişi başına düşen gelir miktarı, suç oranı, işsizlik oranı, ulaşım ve altyapı, yeşil alan, nehir, göl vb. doğal alanlar ölçeğinde çevrebilimle ilgili özellikler ve kentsel doku özellikleri.

Birleşmiş Milletler'in düzenlediği, 1972 yılındaki Stockholm Çevre Konferansı, 1976 yılındaki Kanada Habitat I Zirvesi, 1992 yılındaki Rio Konferansı, 1996 yllındaki İstanbul Habitat II Zirvesi, 2000 yllındaki Binyıl Zirvesi, Johannesburg Kalkınma Konferansı ve 2015 yılındaki Paris İklim Değişikliği Konferansı sürdürülebilirlik kavramına küresel ölçekte dikkat çeken çalışmalar olmuștur. Bu konferanslarda ele alınan kentlerde sürdürülebilirliğin sağlanması ilkeleri o kenti daha yaşanabilir kılacağından dolayı kentsel yaşam kalitesine de etkisi ve katkısı görülmektedir. Tüm bu konferanslardan hareketle Birleşmiş Milletler, kentsel yaşam kalitesi göstergelerini (Demirkaya, 2010:100; Koyuncu, 2011:42-43); sağlık, gıda ve beslenme, eğitim, istihdam, ulaşım, barınma, sosyal faaliyetler, güvenlik, özgürlük, ekonomik ve çevresel sürdürülebilirlik olarak belirlemiștir.

1992 yılında düzenlenen Birleşmiş Milletler Rio Zirvesi'nin bir çıktısı olan Gündem 21 Belgesi'nde ekonomik, sosyal ve çevresel sürdürülebilirliğin sağlanması ve bugünün kaynaklarının gelecek kuşaklara da aktarılması temel amaç olarak belirlenmiştir. Ayrıca belge, yönetimlerde şeffaflık, açılık, halkın karar alma süreçlerine katılımı ilkeleri gereğince kamu sektörü, özel sektör ve sivil toplum işbirliğine dayanan yönetişim kavramı çerçevesinde kentin yaşanabilirlik seviyesinin yükseltilmesi ile kentsel yaşam kalitesinin geliştirilmesine katkıda bulunmaktadır (Atvur, 2009:232).

1961'de kurulan OECD (Ekonomik İşbirliği ve Kalkınma Örgütü), sosyal güvenlik, eğitim sistemleri, yaşlı bakımı gibi hayatın her kesiminden konularla ilgilenen ve dünya üzerindeki insanların ekonomik ve sosyal yaşam kalitesini artıracak politikaları teşvik eden bir örgüttür. OECD’nin bu politikaları uygularken dikkate aldığı göstergeler (stats.oecd.org, E.T. 23.10.2018); konut harcamaları, barınma koşulları, kişi başına düşen gelir miktarı, finansal zenginlik, çalışma saatleri, işsizlik oranı, işsizlik süresi, eğitim süresi, öğrenci başarı oranı, su kirliliği, hava kirliliği, seçmen katılım oranı, yaşam memnuniyeti, sağlık, yaşam süresi, suç oranı, güvenlik, sosyal aktivitelere katılım ve çevre olarak belirlenmiştir.

Avrupa Konseyi tarafından 1992 yılında kabul edilen Avrupa Kentsel Şartı'nda kentsel yaşam kalitesini artırmayı amaçlayan ilkeler, ulaşım ve dolaşım, kentlerde çevre ve doğa, kentlerin fiziki yapıları, tarihi kentsel yapı mirası, konut olanakları, kent güvenliğinin sağlanması ve suçların önlenmesi, kentlerdeki engelliler, kentsel alanlarda spor ve boş zamanları değerlendirme, yerleşimlerde kültür, yerleșimlerde kültürlerarası kaynaşma, kentlerde sağlık, halk katılımı, kent yönetimi, kent planlaması ve kentlerde ekonomik kalkınma olarak gösterilmektedir (www.mimarlarodasiankara.org, E.T. 27.10.2018).

Yaşam kalitesinin belirlenmesinde kullanılan göstergeler nesnel/objektif göstergeler ve öznel/subjektif göstergeler olarak ikiye ayrılmaktadır. Nesnel göstergeler, istatistiki verilere dayanan sayım sonuçları ve raporlar gibi nesnel içerikli bilgilerden oluşmaktadır. Bu göstergeler pek çok ülke tarafından sağlıklı ve güvenilir bir şekilde yapılabildiğinden, değerlendirmeler ve karşılaştırmalar konusunda elverişlidir. Öznel göstergeler ise sosyal koşulların bireysel algılama ve değerlendirmesini vurgulamaktadır. Öznel göstergelerin kişiden kişiye ve toplumdan topluma değişmesi, bu göstergeler arasında bir uzlaşmaya varılmasını ve ortak noktada bir hedefe ulașılmasını güçleștirmektedir (Türksever, 2001:21).

Tablo 1. Yaşam Kalitesinin Belirlenmesinde Kullanılan Nesnel ve Öznel Göstergeler

\begin{tabular}{|l|l|}
\hline Nesnel Göstergeler & Öznel Göstergeler \\
\hline İşsizlik oranı & Yaşam memnuniyeti \\
Yoksulluk oranı & İş memnuniyeti \\
Çalışma saatleri & Sınıf kimliği \\
Okuma oranı & Mutluluk ve hoşnutluk düzeyi \\
Sağlık hizmetlerinden yararlanma & Ekonomik gelir düzeyi \\
\hline
\end{tabular}

Kaynak: Noll, 1996:18. 
Emür ve Onsekiz (2007:367), kentsel yaşam kalitesini ekonomik, toplumsal ve çevresel eksende, nesnel ve öznel değerlerin karșılıklı etkileșimi ile ifade edilen bir kavram olarak tanımlamıștır. Sağlık, güvenlik, huzur ve mutluluk gibi göstergeler öznel değerleri oluştururken, fiziksel çevre, doğal çevre, ekonomik ve sosyal ölçütler ise nesnel göstergeleri oluşturmaktadır.

Kentsel yaşam kalitesi göstergeleri başlığı altında ele alınan ve çeşitli kentsel yaşam kalitesi araştırmaları sonucu ortaya konan göstergeler neticesinde ekonomik, sosyal ve fiziksel bileşenler ekseninde aşağıdaki kentsel yaşam kalitesi göstergeleri tablosu oluşturulmuştur.

Tablo 2: Kentsel Yașam Kalitesi Göstergeleri4

\begin{tabular}{|l|l|l|}
\hline Ekonomik Bileşenler & Sosyal Bileşenler & Fiziksel Bileşenler \\
\hline Gelir-gider & Nüfus & Ulaşım \\
İstihdam & Eğitim & Altyapı \\
Konut & Güvenlik & Rekreasyon alanları \\
Ekonomik kalkınma & Sağlık & Hava ve su kalitesi \\
Turizm & Kültür-sanat faaliyetleri & Geri dönüşüm \\
& Katılım & Yenilenebilir kaynaklar \\
& Yaşam memnuniyeti & Planlı kentleşme \\
& Engelli hakları & Tarihi mirasın korunması \\
& & Kent temizliği \\
\hline
\end{tabular}

\section{YAVAŞ ŞEHIRDE KENTSEL YAŞAM KALİTESININ ÖLÇÜLMESİ: YAVAŞ ŞEHİR SEFERIHISAR ÖRNEĞİ}

"Yavaş Şehirler (Cittaslow) ve Kentsel Yaşam Kalitesi Üzerindeki Etkileri: Seferihisar Halkının Algısı Üzerine Bir Araştırma" başlıklı çalışma için birincil veri toplama aracı olarak hazırlanan anket formu ile Seferihisar'da yavaş şehir hareketinin kentsel yaşam kalitesi üzerindeki etkileri araştırılmıştır.

\subsection{Araştırmanın Amacı}

Araştırmanın amacı sürdürülebilir gelişme kapsamında yavaş şehir hareketinin Türkiye'deki ilk üyesi ve Türkiye Yavaş Şehir Başkenti konumunda olan Seferihisar'da yaşayan halk genelinde gerçekleştirilen anket çalışmasına dayalı olarak yavaş şehir hareketinin kentsel yaşam kalitesi üzerindeki etkilerinin araştırılmasıdır. Bu araştırma yoluyla halkın yavaş şehir hareketine karşı beklenti, tavır ve düşüncelerinin belirlenmesi ile memnuniyet seviyelerinin düşük olduğu durumlara vurgu yapılarak, halkın yaşam kalitesini artıracak faaliyetlerin geliştirilmesine katkıda bulunulması amaçlanmaktadır.

\subsection{Araştırmanın Kapsamı ve Sinırlılıkları}

Sürdürülebilir gelişme düşüncesinden hareketle ortaya çıkan yavaş şehir hareketi ve bu hareketin kentsel yașam kalitesi bağlamında etkilerinin birincil veri toplama aracı olarak anket yöntemi kullanılarak incelendiği çalışma yaş, cinsiyet, gelir durumu, medeni hal vb. durumlar için özel şartlar aramadan Seferihisar'da ikamet eden tüm halkı kapsamaktadır. Araştırmanın sınırlılıkları olarak ise Türkiye'de yavaş şehir hareketine üye olan on beş kent içerisinde ilk ve en uzun üyeliği bulunan Seferihisar'da saha çalışması yapılarak yavaş şehir hareketi ve kentsel yaşam kalitesi arasındaki ilişki Tablo 2'de oluşturulan göstergeler özelinde incelenmiștir.

\subsection{Araștırmanın Veri Toplama Yöntemi ve Verilerin Analizi}

Araştırmada birincil veri toplama aracı olarak anket formu kullanılmıştır. Genel tanımıyla anket, "görüșmecinin daha önce belirlenmiş bir sıralamada ve yapıda olușturulan sorulara karşılık vermesiyle veri elde etme yöntemi" olarak tanımlanmaktadır (Altunışık vd., 2005:68). Bu kapsamda Seferihisar'da yaşayan halk nezdinde, Seferihisar'ın Yavaş Şehir Birliği'ne üyeliğinden sonra yavaş şehir hareketinin kentsel yaşam kalitesi üzerindeki etkilerini ölçmeye yardımcı olacak bir anket çalışması uygulanmıştır.

Evren, araştırmanın sonuçlarının genele yayıldığı en büyük küme, örneklem ise belirli kurallara göre bu kümeden seçilen ve üzerinde araştırma yapılan gruptur (Tekin, 2017:83). Araştırmanın evren ve örneklem büyüklüklerinin belirlenmesinde Sait Gürbüz ve Faruk Şahin'in (2016:132) Sosyal Bilimlerde Araştırma Yöntemleri adlı kitabında istatistiki veriler ile oluşturulan, Farklı Evrenler İçin Kabul Edilebilir Asgari Örneklem Büyüklükleri başlıklı Tablo 5.2'den yararlanılmıştır. Tabloda evren ve evreni karşılayacak \%95 ile \%99 oranlarında güvenilirlik düzeyleri ile gerekli örneklem büyüklükleri gösterilmiştir. Bu tabloya göre araştırmanın evrenini 40.785 nüfusa sahip olan Seferihisar'da yaşayan halkın tümü, araştırmanın asgari örneklemini ise \%95 güvenilirlik düzeyi ile 381 kişi oluşturmaktadır.

\footnotetext{
4 Tablo, kentsel yaşam kalitesi göstergeleri başlı̆̆ı altında farklı araştırmalar sonucu ortaya konan göstergeler çerçevesinde bu çalışmanın yazarları tarafından oluşturulmuştur.
} 
Tablo 2'deki göstergeler referans alınarak oluşturulan anket çalışması, cinsiyet, yaş, Seferihisar'da ikamet süresi ve yavaş șehir kavramı hakkında sahip olunan bilgi sorularını kapsayan birinci bölüm ile ekonomik göstergeler, sosyal göstergeler ve fiziksel göstergelere ait soruları kapsayan ikinci bölüm olmak üzere iki bölümden ve iki sayfadan oluşmaktadır. Örneklem olarak 381 kişiye 2018 yılının Mayıs ayı içerisinde uygulanan anket çalışması, araştırmanın yazarı tarafından birebir ve yerinde gerçekleştirilerek eksik veya hatalı bilgi verilmesinin önüne geçilmiş ve örneklem için gerekli sayıya ulaşılmıștır. Elde edilen verilerin analizinde istatistiksel analiz programı olan IBM SPSS (Statistical Package for Social Sciences) Statistics 25 programı kullanılmıștır. Elde edilen veriler analiz edilirken frekans, ortalama, yüzde alma gibi yöntemler kullanılmıştır. Verilerin iki grup karşılaştırmalarında Student T-Test, normal dağılım gösteren niceliksel verilerin üç ve üzeri grup karşılaştırmaları için ise One-Way Anova Testi kullanılmış ve \%95 güven aralığında anlamlılık p<0.05 düzeyinde değerlendirilmiştir (Altunışık vd., 2005:182-185).

\subsection{Araştırmanın Hipotezleri}

Seferihisar'da yaşayan halkın kentsel yaşam kalitesine ilişkin değerlendirmelerinin belirlenmesi amacını taşıyan araştırmanın temel hipotezleri aşağıda sıralanmıştır.

Hipotez 1 (H1): Kişisel özelliklere ${ }^{5}$ göre katılımcıların fiziksel göstergelere ilişkin görüşlerinde anlamlı bir farklılık yoktur.

Hipotez 2 (H2): Kişisel özelliklere göre katılımcıların ekonomik göstergelere ilişkin görüşlerinde anlamlı bir farklılık yoktur.

Hipotez 3 (H3): Kişisel özelliklere göre katılımcıların sosyal göstergelere ilişkin görüşlerinde anlamlı bir farklılık yoktur.

\subsection{Araştırma Bulgularının Yorumlanması}

Araştırmanın bu bölümünde, veri toplama araçları ile verilerin istatistiksel analizi açıklanmış olup son olarak araştırmanın sonucunda elde edilen bulgular yorumlanmıştır.

\subsubsection{Araştırmanın Güvenilirliği}

Tablo 3: Güvenilirlik Analizi

\begin{tabular}{|l|l|l|l|c|}
\hline \multicolumn{2}{|c|}{ Kiși Sayısı } & Soru Sayıs & Cronbach's Alpha \\
\hline 381 & $\% 100$ & 20 & $\% 100$ &, 880 \\
\hline
\end{tabular}

381 kişi özelinde 20 soru ile yapılan anket araştırmasında 0,88 ile ölçeğin yüksek derecede güvenilir bir ölçek olduğu anlaşılmaktadır.

\subsubsection{Kişisel Özelliklerin Frekans Analizleri}

Tablo 4: Kişisel Özelliklere Ait Bulgular

\begin{tabular}{|l|l|l|l|l|l|}
\hline Cinsiyet & Kişi Sayısı & Yüzde (\%) & İkamet Süresi & Kişi Sayısı & Yüzde (\%) \\
\hline Kadın & 119 & 31,2 & 1 yllan az & 27 & 7,1 \\
\hline Erkek & 262 & 68,8 & $1-5$ yll & 47 & 12,3 \\
\hline Toplam & 381 & 100,0 & $6-10$ yıl & 31 & 8,1 \\
\hline Yaş & Kişi Sayısı & Yüzde (\%) & $11-15$ yıl & 19 & 5,0 \\
\hline 17 ve altı & 7 & 1,8 & $16-20$ yıl & 26 & 6,8 \\
\hline $18-29$ & 82 & 21,5 & 21 yl ve üzeri & 231 & 60,6 \\
\hline $30-45$ & 100 & 26,2 & Toplam & 381 & 100,0 \\
\hline $46-60$ & 118 & 31,0 & Cittaslow Bilgi & Kişi Sayısı & Yüzde (\%) \\
\hline 61 ve üzeri & 74 & 19,4 & Evet & 290 & 76,1 \\
\hline Toplam & 381 & 100,0 & Kismen & 85 & 22,3 \\
\hline & & & Hayır & 6 & 1,6 \\
\hline & & & Toplam & 381 & 100,0 \\
\hline
\end{tabular}

381 katılımcı ile yapılan araştırmanın cinsiyet bulgularının frekans ve yüzdeleri incelendiğinde 119 kişinin kadın (\%31.2) ve 262 kişinin de erkek (\%68.8) olduğu görülmektedir. Erkek katılımcıların sayıca fazla olmasındaki etken, araştırmanın genellikle nüfusun yoğunlaştığı Seferihisar şehir merkezinde yapılmasıdır.

Araştırmanın yaş bulgularının frekans ve yüzde değerleri incelendiğinde katılımcıların \%31'ini oluşturan 118 kişinin 46-60 yaş aralığında olduğu görülmektedir. Daha sonra sırasıyla 30-45 yaş aralığında 100 kişi (\%26.2), 18-29 yaş aralığında 82 kişi (\%21.5), 61 ve üzeri yaş aralığında 74 kişi (\%19.4) ve 17 yaş ve altı

5 Cinsiyet, yaș, Seferihisar'da ikamet etme süresi ve yavaș şehir (cittaslow) kavramı hakkında bilgi sahibi olma durumu. 
aralığında ise 7 kişinin (\%1.8) olmasından hareketle katılımcıların \%50'sinden fazlasının 30 yaş ve üzerinde olduğu görülmektedir.

Araştırmada katılımcıların Seferihisar'da ikamet etme bulguları değerlendirildiğinde 231 kişi ile (\%60.6) büyük çoğunluğun 21 yll ve üzeri süredir Seferihisar'da ikamet ettiği görülmektedir. 47 kişinin (\%12.3) 15 yıl arası süredir, 31 kişinin (\%8.1) 6-10 yıl arası süredir, 27 kişinin $(\% 7,1) 1$ ylldan az süredir, 26 kişinin (\%6,8) 16-20 yıl arası süredir ve 19 kişinin de (\%5) 11-15 yll arası süredir Seferihisar'da ikamet ettiği görülmektedir. Bu durumda katılımcıların çoğunun yavaş șehir üyeliğinin alındığı 2009 yılından önce de Seferihisar'da ikamet ettiği ve bu bakımdan kentsel yaşam kalitesi üzerinde yavaş şehir üyeliği öncesi ve sonrası değerlendirmelerini daha iyi şekilde yapabilecekleri görülmektedir.

Katılımcıların yavaş şehir (cittaslow) hareketi hakkında yeterli bilgiye sahip olma düzeylerine bakıldığında ise 290 kişinin yavaş şehir hareketi hakkında yeterli bilgisinin olduğu, 85 kişinin ise kısmen bilgisinin olduğu görülmektedir. 6 kişi ile katılımcıların çok azının da yavaş şehir hareketi hakkında bilgisinin olmadığı görülmektedir. Bu durumda katılımcıların büyük çoğunluğunun yavaş şehir hareketi hakkında yeterli veya kısmen bir bilgiye sahip olması ve bu ölçüde soruları değerlendirmesi bağlamında çalışmanın yeterliliğinin ve amacının daha iyi anlaşılabileceği düşünülmektedir.

\subsubsection{Kentsel Yașam Kalitesi Göstergelerine İlișkin Betimsel Analizler}

Katılımcıların ekonomik, sosyal ve fiziksel göstergeler çerçevesinde oluşturulan kentsel yaşam kalitesine yönelik sorulara verdiği cevaplar ve yüzdelik dilimleri tablolar halinde gösterilmiștir.

Tablo 5: Fiziksel Göstergelere İlișkin Betimsel İstatistikler

\begin{tabular}{|c|c|c|c|c|c|c|}
\hline \multicolumn{2}{|l|}{ Fiziksel Göstergelere Ait Sorular } & 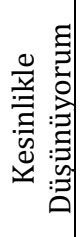 & 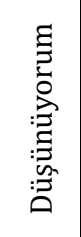 & 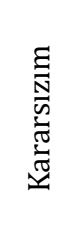 & 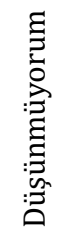 & 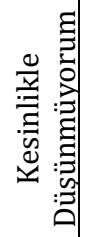 \\
\hline \multirow{2}{*}{$\begin{array}{l}\text { Seferihisar'ın yavaş şehir olmasından sonra kentin ulaşım olanaklarında } \\
\text { gelișme olduğunu düșünüyor musunuz? }\end{array}$} & Sayl & 71 & 203 & 20 & 59 & 28 \\
\hline & $\%$ & 18,6 & 53,3 & 5,2 & 15,5 & 7,3 \\
\hline \multirow{2}{*}{$\begin{array}{l}\text { Seferihisar'ın yavaş șehir olmasından sonra altyapı (yol, su, kanalizasyon vb.) } \\
\text { hizmetlerinin arttığını düșünüyor musunuz? }\end{array}$} & Sayı & 25 & 125 & 17 & 133 & 81 \\
\hline & $\%$ & 6,6 & 32,8 & 4,5 & 34,9 & 21,3 \\
\hline \multirow{2}{*}{$\begin{array}{l}\text { Seferihisar'ın yavaş șehir olmasından sonra rekreasyon alanlarında (park, } \\
\text { bahçe vb.) artış olduğunu düșünüyor musunuz? }\end{array}$} & Sayı & 31 & 159 & 18 & 118 & 55 \\
\hline & $\%$ & 8,1 & 41,7 & 4,7 & 31,0 & 14,4 \\
\hline \multirow{2}{*}{$\begin{array}{l}\text { Seferihisar'ın yavaș șehir olmasından sonra kentteki hava, su, deniz ve toprak } \\
\text { kirliliğini engelleme çalıșmalarında gelișme olduğunu düșünüyor musunuz? }\end{array}$} & Sayı & 28 & 171 & 52 & 74 & 56 \\
\hline & $\%$ & 7,3 & 44,9 & 13,6 & 19,4 & 14,7 \\
\hline \multirow{2}{*}{$\begin{array}{l}\text { Seferihisar'ın yavaş şehir olmasından sonra kentteki temizlik ve katı atık } \\
\text { yönetiminde (geri dönüşüm kutuları vb.) gelişme olduğunu düşünüyor } \\
\text { musunuz? }\end{array}$} & Sayı & 27 & 171 & 24 & 101 & 58 \\
\hline & $\%$ & 7,1 & 44,9 & 6,3 & 26,5 & 15,2 \\
\hline \multirow{2}{*}{$\begin{array}{l}\text { Seferihisar'ın yavaş şehir olmasından sonra kentte yenilenebilir enerji } \\
\text { kaynaklarının (güneş enerjisi, rüzgâr enerjisi vb.) kullanımında artış olduğunu } \\
\text { düșünüyor musunuz? }\end{array}$} & Sayı & 38 & 202 & 58 & 47 & 36 \\
\hline & $\%$ & 10,0 & 53,0 & 15,2 & 12,3 & 9,4 \\
\hline \multirow{2}{*}{$\begin{array}{l}\text { Seferihisar'ın yavaş şehir olmasından sonra planlı kentleșme sürecinde bir } \\
\text { gelișme olduğunu düșünüyor musunuz? }\end{array}$} & Sayı & 16 & 79 & 23 & 126 & 137 \\
\hline & $\%$ & 4,2 & 20,7 & 6,0 & 33,1 & 36,0 \\
\hline \multirow{2}{*}{$\begin{array}{l}\text { Seferihisar'ın yavaş șehir olmasından sonra kentteki tarihi ve kültürel mirasın } \\
\text { iyileștirilip, korunduğunu düșünüyor musunuz? }\end{array}$} & Sayı & 50 & 146 & 24 & 82 & 79 \\
\hline & $\%$ & 13,1 & 38,3 & 6,3 & 21,5 & 20,7 \\
\hline
\end{tabular}

Tablo 5'de katılımcıların fiziksel göstergelere ait betimsel istatistikleri verilmektedir. 381 katılımcı ile yapılan araştırmada sunulan fiziksel göstergelere ait sorulardan kentin ulaşım olanakları, rekreasyon alanlarının artışı, hava, su, deniz ve toprak kirliliğini engelleme çalışmaları, kent temizliği ve katı atık yönetimi, yenilenebilir enerji kaynaklarının kullanımı, tarihi ve kültürel mirasın korunup iyileştirilmesi sorularına çoğunlukla olumlu yanıt verildiği görülmektedir. Kentteki altyapı hizmetleri ve planlı kentleşme sorularına ise katılımcıların çoğunlukla olumsuz yanıt verdiği görülmektedir. 
Tablo 6: Ekonomik Göstergelere İlișkin Betimsel İstatistikler

Ekonomik Göstergelere Ait Sorular

\begin{tabular}{|c|c|c|c|c|c|c|}
\hline \multirow{2}{*}{$\begin{array}{l}\text { Seferihisar'ın yavaş şehir olmasından sonra gelir düzeyinizde bir artış olduğunu } \\
\text { düşünüyor musunuz? }\end{array}$} & Sayl & 33 & 101 & 17 & 207 & 23 \\
\hline & \begin{tabular}{|l|}
$\%$ \\
\end{tabular} & 8,7 & 26,5 & 4,5 & 54,3 & 6,0 \\
\hline \multirow{2}{*}{$\begin{array}{l}\text { Seferihisar'ın yavaş şehir olmasından sonra kentteki istihdam olanaklarının } \\
\text { arttığını düșünüyor musunuz? }\end{array}$} & Sayl & 35 & 174 & 27 & 127 & 18 \\
\hline & $\%$ & 9,2 & 45,7 & 7,1 & 33,3 & 4,7 \\
\hline \multirow{2}{*}{$\begin{array}{l}\text { Seferihisar'ın yavaş şehir olmasının kentin tanıtımında bir reklam aracı olarak } \\
\text { olumlu bir etkisinin olduğunu düşünüyor musunuz? }\end{array}$} & \begin{tabular}{|l} 
Sayl \\
\end{tabular} & 83 & 211 & \begin{tabular}{|l|}
10 \\
\end{tabular} & 63 & 14 \\
\hline & $\%$ & 21,8 & 55,4 & 2,6 & 16,5 & 3,7 \\
\hline \multirow{2}{*}{$\begin{array}{l}\text { Seferihisar'ın yavaș şehir olmasından sonra kentteki konut kalitesi ve konut } \\
\text { edinme olanaklarında artıș olduğunu düșünüyor musunuz? }\end{array}$} & Sayı & 63 & 195 & 16 & 79 & 28 \\
\hline & $\%$ & 16,5 & 51,2 & 4,2 & 20,7 & 7,3 \\
\hline \multirow{2}{*}{$\begin{array}{l}\text { Seferihisar'ın yavaş șehir olmasından sonra kentteki yatırımların artması } \\
\text { boyutuyla yerel ekonomik kalkınmanın arttığını düșünüyor musunuz? }\end{array}$} & Sayl & 47 & 176 & 33 & 93 & 32 \\
\hline & $\%$ & 12,3 & 46,2 & \begin{tabular}{|l}
8,7 \\
\end{tabular} & 24,4 & 8,4 \\
\hline \multirow{2}{*}{$\begin{array}{l}\text { Seferihisar'ın yavaş şehir olmasından sonra kentteki turizm sektöründe bir } \\
\text { gelișme olduğunu düșünüyor musunuz? }\end{array}$} & \begin{tabular}{|l} 
Sayl \\
\end{tabular} & 75 & 201 & 21 & 61 & 23 \\
\hline & $\%$ & 19,7 & 52,8 & 5,5 & 16,0 & 6,0 \\
\hline
\end{tabular}

Tablo 6'da katılımcıların ekonomik göstergelere ait betimsel istatistikleri verilmektedir. 381 katılımcı ile yapılan araștırmada Seferihisar'ın yavaş şehir olmasından sonra kentteki istihdam olanaklarında artış yaşandığı, yavaş şehir hareketinin olumlu bir reklam aracı olduğu, konut kalitesinde ve konut edinme olanaklarında artış olduğu, kentin yerel ekonomisinin canlandığı ve turizm sektöründe olumlu bir gelişme yaşandığı belirtilen sorulara \%50'den fazla düşünüyorum yanıtı verilmiştir. Ekonomik göstergelere ilişkin sorular içerisinde sadece gelir düzeyinde yaşanan artış sorusuna katılımcıların yüzde 60,3'ü Seferihisar'ın yavaş şehir olmasından sonra gelir düzeylerinde bir artış olduğunu düşünmemektedir.

Tablo 7: Sosyal Göstergelere İlișkin Betimsel İstatistikler

\begin{tabular}{|c|c|c|c|c|c|c|}
\hline \multicolumn{2}{|l|}{ Sosyal Göstergelere Ait Sorular } & 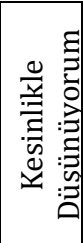 & 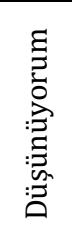 & 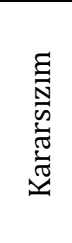 & 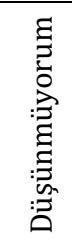 & 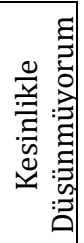 \\
\hline \multirow{2}{*}{$\begin{array}{l}\text { Seferihisar'ın nüfusunun artmasının yaşam kaliteniz üzerinde olumlu bir etki } \\
\text { gösterdiğini düșünüyor musunuz? }\end{array}$} & Sayl & 25 & 91 & 32 & 168 & 65 \\
\hline & $\%$ & 6,6 & 23,9 & 8,4 & 44,1 & 17,1 \\
\hline \multirow{2}{*}{$\begin{array}{l}\text { Seferihisar'ın yavaş şehir olmasından sonra kentin güvenlik düzeyinde bir artış } \\
\text { olduğunu düşünüyor musunuz? }\end{array}$} & Sayl & 40 & 167 & 53 & 72 & 49 \\
\hline & $\%$ & 10,5 & 43,8 & 13,9 & 18,9 & 12,9 \\
\hline \multirow{2}{*}{$\begin{array}{l}\text { Seferihisar'ın yavaş şehir olmasından sonra kültür ve sanat faaliyetlerinde bir } \\
\text { artış olduğunu düșünüyor musunuz? }\end{array}$} & Sayı & 91 & 230 & 19 & 25 & 16 \\
\hline & $\%$ & 23,9 & 60,4 & 5,0 & 6,6 & 4,2 \\
\hline \multirow{2}{*}{$\begin{array}{l}\text { Seferihisar'ın yavaş șehir olmasından sonra kentin sağlık hizmetlerinde bir } \\
\text { gelişme olduğunu düșünüyor musunuz? }\end{array}$} & Sayl & 42 & 159 & 58 & 70 & 52 \\
\hline & $\%$ & 11,0 & 41,7 & 15,2 & 18,4 & 13,6 \\
\hline \multirow{2}{*}{$\begin{array}{l}\text { Seferihisar'ın yavaş şehir olmasından sonra siyasal katılım ve bilgi edinme } \\
\text { konularında olumlu bir gelişme olduğunu düșünüyor musunuz? }\end{array}$} & Sayı & 19 & 96 & 67 & 161 & 38 \\
\hline & $\%$ & 5,0 & 25,2 & 17,6 & 42,3 & 10,0 \\
\hline \multirow{2}{*}{$\begin{array}{l}\text { Seferihisar'ın yavaş şehir olmasından sonra yaşam memnuniyeti seviyenizde } \\
\text { artıș olduğunu düșünüyor musunuz? }\end{array}$} & Sayı & 28 & 142 & 31 & 130 & 50 \\
\hline & $\%$ & 7,3 & 37,3 & 8,1 & 34,1 & 13,1 \\
\hline
\end{tabular}

Tablo 7'de katılımcıların sosyal göstergelere ait betimsel istatistikleri verilmektedir. 381 katılımcı ile yapılan araștırmada \%50'den fazla düșünüyorum yanıtı ile Seferihisar'ın yavaș șehir olmasından sonra kentin güvenlik düzeyi, kültür sanat faaliyetleri, sağlık hizmetleri gibi konularda olumlu bir gelişme olduğu görülmektedir. Nüfus artışının yaşam kalitesi üzerindeki etkileri, siyasal katılım ve bilgi edinme konularında ise \%50'den fazla düşünmüyorum yanıtı ile olumsuz bir düşünce hâkimdir. Yaşam memnuniyeti seviyesindeki artış sorusunda ise hem düşünüyorum hem de düşünmüyorum yanıtlarında yaklaşık olarak bir eşitlik görülmektedir.

\subsubsection{Kişisel Özellikler ve Kentsel Yaşam Kalitesi Göstergelerinin Analizi}

Bu bölümde cinsiyet, yaş ve Seferihisar'da ikamet etme süresi ve yavaş şehir hareketi hakkında sahip olunan bilgi durumu olarak sınıflandırılan kişisel özellikler ile fiziksel, ekonomik ve sosyal göstergelerden oluşan soruların Student T-Test ve One-Way Anova Testi ile eşleştirmesi yapılmıştır. Eşleştirme sonucu oluşturulan tablolar çerçevesinde ise " $\mathrm{p}<0,05$ " düzeyinde anlamlılık değerlendirmesi yapılmıştır. 
Okan Akpınar, Ethem Kadri Pektaş; Yavaş Şehirler (Cittaslow) Ve Kentsel Yaşam Kalitesi Üzerindeki Etkileri: Seferihisar Halkının Algısı Üzerine Bir Araștırma

\subsubsection{Fiziksel göstergelere ilişskin görüşlerin değerlendirilmesi}

Tablo 8: Cinsiyete Göre Fiziksel Göstergelere İlișkin Görüșler

\begin{tabular}{|c|c|c|c|c|}
\hline & \multicolumn{2}{|c|}{ Cinsiyet } & \multirow{2}{*}{ ap } \\
\hline & & Erkek $(n=262)$ & $\operatorname{Kad} ı n(n=119)$ & \\
\hline \multirow{2}{*}{ Fiziksel Göstergeler } & Ort \pm SD & $3,00 \pm 0,85$ & $2,95 \pm 0,84$ & \multirow{2}{*}{0,600} \\
\hline & Min-Max (Medyan) & $1,00-5,00(3,00)$ & $1,00-5,00(2,87)$ & \\
\hline
\end{tabular}

Tablo 8'de cinsiyete göre katılımcıların fiziksel göstergelere ilişkin görüş puanı istatistiksel olarak anlamlı bir farklılık göstermemektedir ( $p>0,05)$.

Tablo 9: Yașa Göre Fiziksel Göstergelere İlișkin Görüșler

\begin{tabular}{|c|c|c|c|c|c|c|c|}
\hline & \multicolumn{5}{|c|}{ Yaș } & \multirow{2}{*}{$\mathrm{Cp}$} \\
\hline & & 17 ve altı & $18-29$ & $30-45$ & $46-60$ & 61 ve üzeri & \\
\hline \multirow[b]{2}{*}{$\begin{array}{l}\text { Fiziksel } \\
\text { Göstergeler }\end{array}$} & Ort $\pm S D$ & $2,14 \pm 0,47$ & $2,88 \pm 0,85$ & $3,13 \pm 0,81$ & $3,02 \pm 0,84$ & $2,94 \pm 0,85$ & \multirow[b]{2}{*}{0,020} \\
\hline & $\begin{array}{l}\text { Min-Max } \\
\text { (Medyan) }\end{array}$ & $\begin{array}{c}1,50-3,00 \\
(2,00)\end{array}$ & $\begin{array}{c}1,00-5,00 \\
(2,93)\end{array}$ & $\begin{array}{c}1,00-5,00 \\
(3,12)\end{array}$ & $\begin{array}{c}1,00-5,00 \\
(3,00)\end{array}$ & $\begin{array}{c}1,00-5,00 \\
(2,81)\end{array}$ & \\
\hline
\end{tabular}

Tablo 9'da H1 hipotezinde yaşa göre katılımcıların fiziksel göstergelere ilişkin görüşlerinde anlamlı bir farklılık yoktur hipotezi reddedilerek, yaşa göre katılımcıların fiziksel göstergelere ilişkin görüş puanı istatistiksel olarak anlamlı bir farklılık göstermektedir $(\mathrm{p}<0,05)$. Yapılan ikili karşılaştırmalara göre 30-45 yaş aralı̆̆ındaki katılımcıların kentsel yaşam kalitesine yönelik fiziksel göstergelerine ilişkin görüş puanı, 17 ve altı yaş katılımcılardan daha yüksek bulunmuştur $(\mathrm{p}=0,020 ; \mathrm{p}<0,05)$. Bu durum 30-45 yaş aralığındaki katılımcıların fiziksel göstergelere yönelik 17 ve altı yaş katılımcılara nazaran daha olumsuz algılara sahip olduğunu göstermektedir. Diğer gruplar arasında istatistiksel olarak anlamlı farklılık saptanmamıştır $(p>0,05)$.

Tablo 10: Seferihisar'da İkamet Etme Süresine Göre Fiziksel Göstergelere İlișkin Görüșler

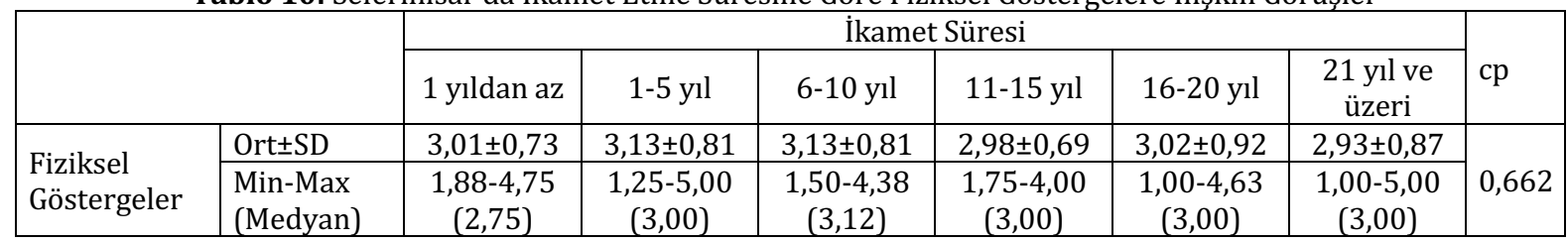

"One-Way Anova"

Tablo 10'da Seferihisar'da ikamet etme süresine göre katılımcıların fiziksel göstergelere ilişskin görüş puanı istatistiksel olarak anlamlı bir farklılık göstermemektedir ( $\mathrm{p}>0,05)$.

Tablo 11: Yavaș Şehir (Cittaslow) Kavramı Hakkında Sahip Olunan Bilgiye Göre Fiziksel Göstergelere İlișkin Görüşler

\begin{tabular}{|c|c|c|c|c|c|}
\hline & \multicolumn{3}{|c|}{ Yavaș Șehir (Cittaslow) Kavramı Hakkında Bilgi } & \multirow[b]{2}{*}{$\mathrm{Cp}$} \\
\hline & & Evet & Kismen & Hayır & \\
\hline \multirow{2}{*}{ Fiziksel Göstergeler } & Ort \pm SD & $2,96 \pm 0,87$ & $3,10 \pm 0,74$ & $2,81 \pm 1,02$ & \multirow[t]{2}{*}{0,343} \\
\hline & Min-Max (Medyan) & $1,00-5,00(3,00)$ & $1,25-4,75(3,00)$ & $1,50-4,38(3,00)$ & \\
\hline
\end{tabular}

Tablo 11'de yavaş şehir (cittaslow) kavramı hakkında bilgi durumuna göre katılımcıların fiziksel göstergelere ilişkin görüş puanı istatistiksel olarak anlamlı bir farklılık göstermemektedir $(p>0,05)$.

\subsubsection{Ekonomik göstergelere ilișkin görüșlerin değerlendirilmesi}

Tablo 12: Cinsiyete Göre Ekonomik Göstergelere İlișkin Görüșler

\begin{tabular}{|c|c|c|c|c|}
\hline & & \multicolumn{2}{|c|}{ Cinsiyet } & \multirow{2}{*}{ ap } \\
\hline & & Erkek $(n=262)$ & $\operatorname{Kad} ı(n=119)$ & \\
\hline \multirow{2}{*}{ Ekonomik Göstergeler } & Ort \pm SD & $2,70 \pm 0,78$ & $2,49 \pm 0,68$ & \multirow{2}{*}{0,140} \\
\hline & Min-Max (Medyan) & $1,00-5,00(2,66)$ & $1,00-4,33(2,33)$ & \\
\hline
\end{tabular}

Tablo 12'de cinsiyete göre katılımcıların ekonomik göstergelere ilişkin görüş puanı istatistiksel olarak anlamlı bir farklılık göstermemektedir $(\mathrm{p}>0,05)$.

Tablo 13: Yașa Göre Ekonomik Göstergelere İlișkin Görüșler

\begin{tabular}{|l|l|c|c|c|c|c|l|}
\hline \multirow{2}{*}{} & \multicolumn{5}{|c|}{ Yaș } & \multirow{2}{*}{ Cp } \\
\cline { 3 - 8 } & 17 ve altı & $18-29$ & $30-45$ & $46-60$ & 61 ve üzeri & \\
\hline & Ort \pm SD & $2,09 \pm 0,25$ & $2,41 \pm 0,81$ & $2,66 \pm 0,79$ & $2,59 \pm 0,66$ & $2,97 \pm 0,71$ & 0,000 \\
\hline
\end{tabular}


Okan Akpınar, Ethem Kadri Pektaş; Yavaş Şehirler (Cittaslow) Ve Kentsel Yaşam Kalitesi Üzerindeki Etkileri: Seferihisar Halkının Algısı Üzerine Bir Araştırma

\begin{tabular}{|l|l|c|c|c|c|c|c|}
\hline Ekonomik & Min-Max & $1,83-2,50$ & $1,00-5,00$ & $1,00-4,50$ & $1,00-4,33$ & $1,00-4,33$ \\
Göstergeler & (Medyan) & $(2,00)$ & $(2,33)$ & $(2,66)$ & $(2,50)$ & $(2,83)$ & \\
\hline
\end{tabular}

Tablo 13'de H2 hipotezinde yaşa göre katılımcıların ekonomik göstergelere ilişkin görüşlerinde anlamlı bir farklılık yoktur hipotezi reddedilerek, yaşa göre katılımcıların ekonomik göstergelere ilişkin görüş puanı istatistiksel olarak anlamlı bir farklılık göstermektedir $(\mathrm{p}<0,05)$. Yapılan ikili karşılaștırmalara göre 61 ve üzeri yaş katılımcıların kentsel yaşam kalitesine yönelik ekonomik göstergelerine ilişkin görüş puanı, 17 ve altı yaş katılımcılardan daha yüksek bulunmuştur $(\mathrm{p}=0,000 ; \mathrm{p}<0,05)$. Bu durum 61 ve üzeri yaş aralığındaki katılımcıların ekonomik göstergelere yönelik 17 ve altı yaş katılımcılara nazaran daha olumsuz algılara sahip olduğunu göstermektedir. Diğer gruplar arasında istatistiksel olarak anlamlı farklılık saptanmamıştır $(\mathrm{p}>0,05)$.

Tablo 14: Seferihisar'da İkamet Etme Süresine Göre Ekonomik Göstergelere İlișkin Görüșler

\begin{tabular}{|c|c|c|c|c|c|c|c|c|}
\hline & \multicolumn{6}{|c|}{ İkamet Süresi } & \multirow[b]{2}{*}{$\mathrm{cp}$} \\
\hline & & 1 yıldan az & $1-5$ yll & $6-10$ yil & $11-15$ yıl & $16-20$ yll & $\begin{array}{l}21 \text { yll ve } \\
\text { üzeri }\end{array}$ & \\
\hline \multirow[b]{2}{*}{$\begin{array}{l}\text { Ekonomik } \\
\text { Göstergeler }\end{array}$} & Ort \pm SD & $2,61 \pm 0,65$ & $2,41 \pm 0,84$ & $2,40 \pm 0,64$ & $2,78 \pm 0,67$ & $2,67 \pm 0,74$ & $2,70 \pm 0,76$ & \multirow[b]{2}{*}{0,098} \\
\hline & $\begin{array}{l}\text { Min-Max } \\
\text { (Medyan) }\end{array}$ & $\begin{array}{c}1,17-4,33 \\
(2,66)\end{array}$ & $\begin{array}{c}1,00-4,33 \\
(2,33)\end{array}$ & $\begin{array}{c}1,00-4,00 \\
(2,33)\end{array}$ & $\begin{array}{c}1,83-4,00 \\
(2,66)\end{array}$ & $\begin{array}{c}1,50-4,00 \\
(2,50)\end{array}$ & $\begin{array}{c}1,00-5,00 \\
(2,66)\end{array}$ & \\
\hline
\end{tabular}

"One-Way Anova"

Tablo 14'de Seferihisar'da ikamet etme süresine göre katılımcıların ekonomik göstergelere ilişkin görüş puanı istatistiksel olarak anlamlı bir farklılık göstermemektedir ( $\mathrm{p}>0,05)$.

Tablo 15: Yavaş Șehir (Cittaslow) Kavramı Hakkında Sahip Olunan Bilgiye Göre Ekonomik Göstergelere İlișkin Görüssler

\begin{tabular}{|l|l|c|c|c|c|}
\hline \multicolumn{2}{|c|}{} & \multicolumn{3}{|c|}{ Yavaș Șehir (Cittaslow) Kavramı Hakkında Bilgi } \\
\cline { 3 - 5 } & Evet & Kısmen & Hayır & Cp \\
\hline \multirow{2}{*}{ Ekonomik Göstergeler } & Ort \pm SD & $2,63 \pm 0,76$ & $2,68 \pm 0,73$ & $2,36 \pm 0,90$ & 0,579 \\
\cline { 2 - 5 } & Min-Max (Medyan) & $1,00-5,00(2,66)$ & $1,00-4,33(2,66)$ & $1,33-4,00(2,08)$ & \\
\hline
\end{tabular}

Tablo 15'de yavaş şehir (cittaslow) kavramı hakkında sahip olunan bilgi durumuna göre katılımcıların ekonomik göstergelere ilişkin görüş puanı istatistiksel olarak anlamlı bir farklılık göstermemektedir $(\mathrm{p}>0,05)$.

\subsubsection{Sosyal göstergelere ilişkin görüşlerin değerlendirilmesi}

Tablo 16: Cinsiyete Göre Sosyal Göstergelere İlișkin Görüșler

\begin{tabular}{|l|l|c|c|l|}
\hline \multicolumn{2}{|c|}{} & \multicolumn{2}{|c|}{ Cinsiyet } & \multirow{2}{*}{ ap } \\
\cline { 2 - 4 } \multirow{2}{*}{ Sosyal Göstergeler } & Ort \pm SD & $2,94 \pm 0,75$ & $2,83 \pm 0,68$ & \multirow{2}{*}{0,210} \\
\cline { 2 - 4 } & Min-Max (Medyan) & $1,00-5,00(3,00)$ & $1,00-5,00(2,83)$ & \\
\hline "Student t-test"
\end{tabular}

Tablo 16'da cinsiyete göre katılımcıların sosyal göstergelere ilişkin görüş puanı istatistiksel olarak anlamlı bir farklılık göstermemektedir $(\mathrm{p}>0,05)$.

Tablo 17: Yașa Göre Sosyal Göstergelere İlișkin Görüșler

\begin{tabular}{|c|c|c|c|c|c|c|c|}
\hline & \multicolumn{5}{|c|}{ Yaș } & \multirow{2}{*}{$\mathrm{cp}$} \\
\hline & & 17 ve altı & $18-29$ & $30-45$ & $46-60$ & 61 ve üzeri & \\
\hline \multirow[b]{2}{*}{$\begin{array}{l}\text { Sosyal } \\
\text { Göstergeler }\end{array}$} & Ort \pm SD & $2,47 \pm 0,64$ & $2,83 \pm 0,81$ & $3,01 \pm 0,73$ & $2,92 \pm 0,63$ & $2,87 \pm 0,77$ & \multirow[b]{2}{*}{0,246} \\
\hline & $\begin{array}{l}\text { Min-Max } \\
\text { (Medyan) }\end{array}$ & $\begin{array}{c}1,50-3,50 \\
(2,50)\end{array}$ & $\begin{array}{c}1,00-5,00 \\
(2,66)\end{array}$ & $\begin{array}{c}1,00-5,00 \\
(3,00)\end{array}$ & $\begin{array}{c}1,00-4,67 \\
(3,00)\end{array}$ & $\begin{array}{c}1,50-4,33 \\
(3,00)\end{array}$ & \\
\hline
\end{tabular}

"One-Way Anova"

Tablo 17'de yaşa göre katılımcıların sosyal göstergelere ilişkin görüş puanı istatistiksel olarak anlamlı bir farklılık göstermemektedir ( $\mathrm{p}>0,05)$.

Tablo 18: Seferihisar'da İkamet Etme Süresine Göre Sosyal Göstergelere İlișkin Görüșler

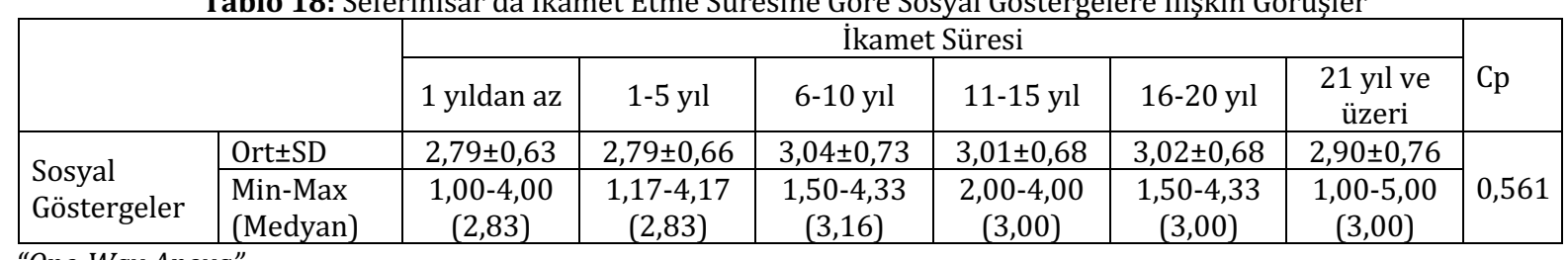

"One-Way Anova" 
Tablo 18'de Seferihisar'da ikamet etme süresine göre katılımcların sosyal göstergelere ilişkin görüş puanı istatistiksel olarak anlamlı bir farklılık göstermemektedir $(\mathrm{p}>0,05)$.

Tablo 19: Yavaș Șehir (Cittaslow) Kavramı Hakkında Sahip Olunan Bilgiye Göre Sosyal Göstergelere İlișkin Görüşler

\begin{tabular}{|c|c|c|c|c|c|}
\hline & \multicolumn{3}{|c|}{ Yavaș Șehir (Cittaslow) Kavramı Hakkında Bilgi } & \\
\hline & & Evet & Kismen & Hayır & $\mathrm{Cp}$ \\
\hline \multirow{2}{*}{ Sosyal Göstergeler } & Ort \pm SD & $2,89 \pm 0,74$ & $2,96 \pm 0,69$ & $2,83 \pm 0,82$ & \multirow{2}{*}{0,695} \\
\hline & Min-Max (Medyan) & $1,00-5,00(3,00)$ & $1,00-4,00(3,00)$ & $1,50-3,67(2,91)$ & \\
\hline
\end{tabular}

Tablo 19'da yavaş şehir (cittaslow) kavramı hakkında bilgi durumuna göre katılımcıların sosyal göstergelere ilişkin görüş puanı istatistiksel olarak anlamlı bir farklılık göstermemektedir ( $p>0,05)$.

\section{SONUÇ VE ÖNERILER}

Yavaş șehir hareketi ekonomik, sosyal ve çevresel sürdürülebilirliği sağlayarak o bölgede yaşayan halkın kentsel yaşam kalitesini artırmayı amaçlayan bir harekettir. Bu kapsamda 2009 yllından bu zamana Yavaş Şehir Birliği'ne üye olan Seferihisar'da halkın yaşam kalitesinin ölçülmesi adına bir anket araştırması yapılmıştır. 381 kişi örnekleminde yapılan araştırmada katılımcıların yaş aralığının genellikle 30 yaş ve üzeri olduğu, Seferihisar'da ikamet etme sürelerinin ise çoğunlukla 21 yll ve üzeri olduğu görülmektedir. Katılımcıların yavaş șehir kavramı hakkında da yeterli bilgiye sahip olmaları Seferihisar'ın 2009 yılında elde ettiği Yavaş Şehir Birliği'ne üyelik statüsünden önceki ve sonraki dönemlerini bilmeleri ve bu doğrultuda sorulan sorulara net bir şekilde cevap vermeleri açısından önem teşkil etmektedir.

Fiziksel göstergelere ait sorulara verilen cevaplar incelendiğinde ulaşım, hava, su ve toprak kirliliğini engelleme, kent temizliği ve katı atık geri dönüşümü, yenilenebilir enerji kaynaklarının kullanımı gibi konularda katılımcıların olumlu bir görüşe sahip olduğu görülmektedir. Belediye bünyesinde alınan yeni otobüsler ve oluşturulan yeni otobüs hatları ekseninde ulaşımın kolaylaşması kentsel yaşam kalitesini artırıcı gelişmeler olarak görülmektedir. Hava, su, toprak kirliğini engelleme çalışmaları neticesinde çöp konteynırlarının etrafının kapatılması, rüzgâr ve güneș enerjisi gibi yenilenebilir enerji kaynaklarının kent etrafında yapılan park ve bahçelerde kullanılması, deniz kirliliği ile mücadele kapsamında alınan, temiz deniz ve plajlara sahip olmanın göstergesi olan mavi bayrak etiketleri, geri dönüşüm alanında kentin belirli noktalarına geri dönüşüm kutularının konulması gibi çalışmalar kentsel yaşam kalitesini artıran politikalar olarak görülmektedir. Planlı kentleșme politikalarının uygulanması, altyapı hizmetlerinin artırılması, tarihi ve kültürel yapıların korunması konusunda ise katılımcılar nezdinde olumsuz bir görüş hâkimdir. Nüfus yoğunluğu ile birlikte artan konut ihtiyacı kentteki yapılaşma oranını artırmakta ve bu yapılaşmanın da planlı bir şekilde ilerlememesi doğal çevrenin tahribatına neden olmaktadır. Plansız kentleşmenin bir sonucu olarak da tarihi ve kültürel yapılara gereken değerin verilmemesi bu yapıların yok olmasına neden olmaktadır. Diğer bir olumsuz sonuç ise altyapı politikalarında yaşanmaktadır. Yağmurlar ile beraber kanalizasyon sistemlerinin çalıșmaması, yolların henüz tamamlanmamış olması ve esnafın kaldırım işgali gibi durumların halkın gözünde kentsel yaşam kalitesini azaltıcı etkiye sahip oldukları görülmektedir.

Ekonomik göstergelere ait sorulara verilen cevaplar incelendiğinde halk tarafından genel olarak olumlu bir yaklaşım görülmektedir. Yavaș şehir hareketinin kentin tanıtımındaki olumlu etkisi kentteki yatırımcıları da artırarak kentte istihdam olanaklarını geliştirmiş, bunun yanı sıra turizm potansiyelinin artırmasıyla ve yerel ürün ve üreticilerin teşvik edilmesiyle de yerel ekonominin canlanmasını sağlamıștır. Ekonomik göstergelere ait sorular üzerinden yapılan araştırma sonucu halkın gelir düzeyindeki artışta ise tam tersi olarak olumsuz bir düşünce hâkimdir. Bu durumun temel nedeni ise yavaş şehir hareketi ile ünlenen Seferihisar'a gelen yabancı yatırımcıların yerel halkın iş potansiyellerini elinden alarak onlara yatırım alanı bırakmaması ve popülerlik kazanan Seferihisar'da fiyatların artması olarak görülmektedir.

Sosyal göstergelere ait sorulara verilen cevaplar incelendiğinde ise güvenlik, sağlık, kültür ve sanat faaliyetlerinde olumlu bir artış olduğu görülmektedir. Sığacık Kaleiçi bölgesinde gerçekleșen etkinlikler, Tohum Takas Şenlikleri, Mandalina Şenlikleri, yerel gıda pazarları, tiyatro topluluklarının kurulması ve Kadın Emeği Evleri'nin açılması ile yerel zanaatların yaşatılması kentteki kültür ve sanat faaliyetlerinin geliştiğine dair örnek olarak gösterilmektedir. Bunun yanı sıra nüfus artışının halkın yaşam kalitesi üzerindeki etkisi katılımcıların \%50'sinden fazlası tarafından olumsuz olarak karşılanmaktadır. Nüfusun artmasıyla beraber artan betonlaşma, çevre ve kaynak tahribatı, kentin kalabalıklaşması gibi etkenler halk tarafından yaşam kalitesini düşürücü etkenler olarak görülmektedir. Katılım ve bilgi edinme konularında da katılımcıların \%50'den fazlası olumsuz görüş bildirmektedir. Belediye bünyesinde alınan kararların ve yapılacak etkinliklerin halka danışılmadan gerçekleştirilmesi, halk açısından kentsel yaşam kalitesinin artmasının önündeki engel olarak görülmektedir. 
Elde edilen sonuç ve bulgular ile yapılan gözlemlerden hareketle; yavaş şehirler ve kentsel yaşam kalitesi ilişkisi kapsamında, Seferihisar'ın kentsel yașam kalitesinin artırılmasına katkı verme amacına yönelik olarak şu öneriler getirilebilir:

- Kentin popülerlik kazanması sebebiyle gerçekleşen hızlı göç sonucu kente gelen yabancı yatırımcıların yerel üreticiyi zarara uğratması ve gelirini düşürmesi sorunu ile ilgili olarak; yapılacak düzenlemeler ile kentteki ekonomik oluşumlarda yerel üreticilere çeşitli teşvikler verilerek yerel üreticilerin yabancı yatırımcılar karşısında zor durumda kalmaları önlenebilir.

- Kente gelen göç ile birlikte artan nüfus, halkın kentsel yaşam kalitesini olumsuz etkilemektedir. Bu kapsamda yavaş şehir hareketinin 50.000 kişi kriteri olarak koyduğu nüfus politikası da göz önünde bulundurularak imar ve ruhsat izni düzenlemeleri ile yaşanan ve/veya yaşanabilecek nüfus artışı belli seviyelerde kontrol altına alınabilir.

- Siyasal katılım ve bilgi edinme konularına önem verilerek, halk yapılacak faaliyetlerde daha şeffaf olarak bilgilendirilmeli ve karar alma süreçlerine dâhil edilmelidir. Belediye veya kaymakamlık bünyesinde yapılacak faaliyetler elektronik yolla ve kentin belirli noktalarına konulacak ilan panoları veya mevcut ilan panolarının iyileştirilmesi ile halka en hızlı ve açık şekilde ulaştırılabilir.

- Altyapı politikalarının iyileştirilmesi ile kanalizasyon sistemleri geliștirilmeli ve yollardaki bozukluklar giderilmelidir.

- Engelli vatandaşların daha rahat şekilde yaşamaları adına kamu ve özel kuruluşlar ile kent genelindeki kaldırımlarda engelli rampaları ve engelli şeritlerinin artırılması hedeflenmelidir. $\mathrm{Bu}$ kapsamda ilk olarak kentteki esnafın kaldırım işgalinin önüne geçilmesiyle başta engelli vatandaşların sonra da genel olarak halkın kaldırımları etkin kullanımı sağlanabilir. Ayrıca toplu taşıma araçlarında engelli bireylerin de rahat şekilde kullanabilecekleri araçlar tercih edilebilir.

- Planlı kentleşme politikalarının uygulanması ile kentteki betonlaşma azaltılmalı ve tarıma elverişli alanların imara açılmasının önüne geçilmelidir. Seferihisar Belediyesi'nin hazırlayacağı imar planlaması çerçevesinde kentteki yeşil alanların ve tarım alanlarının koruma altına alınması ile kentin betonlaşma oranı azaltılabilir ve tarım arazilerinin yok olması engellenebilir.

- Tarihi ve kültürel yapılar daha sağlıklı șekilde korunarak gelecek kușaklara aktarılmalıdır. Kentteki tarihi ve kültürel bölgelerin haritası çıkarılarak bu bölgeler ve çevresinde koruma alanları oluşturulup, bu yapılar iyileştirilmelidir. Bu koruma alanlarının belirlenmesi ile tarihi ve kültürel bölgelerin yakınlarında oluşabilecek yapılaşmanın da önüne geçilmesi ve bu bölgelerin daha sağlıklı bir çevreye kavuşturulması gerçekleştirilebilir.

- Genel kent temizliğine dikkat edilmeli ve çöp konteynırlarının daha steril olması sağlanmalıdır. Bu kapsamda oluşturulacak bir uygulama ile günlük çöp atma saatleri belirlenebilir ve bu saatler içerisinde çöplerin belediye görevlileri tarafından toplanmasıyla da kent daha temiz bir görüntüye kavuşabilir ve çöplerin oluşturduğu koku ve görüntü kirliliğinin de önüne geçilebilir.

- Trafiğin azaltılması ve hava kirliliğinin kontrol altına alınması bağlamında toplu taşıma teşvik edilmelidir. Bu kapsamda Seferihisar ve çevresine geniş ölçekli bir toplu taşıma ağı sağlanabilir. Ayrıca kentin merkezinde belirli noktalara bisiklet durakları konularak bisiklet yolları geliştirilebilir. Halkın kısa mesafelerde bisiklet kullanımının teşvik edilmesi yoluyla hem araç trafiği yoğunluğu hem de hava kirliliği sorunu azaltılabilir. 


\section{KAYNAKÇA}

Altunışık, R., Coşkun, R., Bayraktaroğlu, S., Yıldırım, E. (2005), Sosyal Bilimlerde Araştırma Yöntemleri SPSS Uygulamall, İstanbul: Sakarya Kitabevi.

Altuntaş, A. (2012), "Sürdürülebilir Toplumlar ve Metropollerin Baskılarından Kurtulmak için Alternatif Bir Yol: Sürdürülebilir Kentler”, Mustafa Kemal Üniversitesi Sosyal Bilimler Enstitüsü Dergisi, Sayı.17, 135-148.

Atvur, S. (2009), "Yerel Gündem 21 ve Çevre: Antalya Kent Konseyi Örneği", Cumhuriyet Üniversitesi Sosyal Bilimler Dergisi, Sayı.2, 231-241.

Cittaslow (2017). Cittaslow International Charter. Orvieto-Italy: International Cittaslow:

http://www.cittaslow.org/sites/default/files/content/page/files/257/charter_cittaslow_en_05_18.pdf?g $\mathrm{a}=2.65561451 .438208676 .1532094650-1758220794.1519427949$

Coşar, Y. (2013), "Yavaş Şehir (Cittaslow) Olgusunun Turist Davranışları ve Yerel Halkın Kentsel Yaşam Kalitesi Algısına Etkileri”, Doktora Tezi, Dokuz Eylül Üniversitesi Sosyal Bilimler Enstitüsü, İzmir.

Demirkaya, Y. (2010), Çekmeköy'ün Sosyo-Ekonomik Yapısı ve Kentsel Yaşam Kalitesi, İstanbul: Çekmeköy Belediye Başkanlığı.

Deniz, T. (2017), "Hızlı Dünyada Sürdürülebilir Mekânlar: Sakin Kentler", İnsan ve Toplum Bilimleri Araştırmaları Dergisi, Sayı.3, 1399-1412.

Ekşioğlu, A. (2011), "Kentsel Yaşam Kalitesi ve İstanbul Örneği”, Yüksek Lisans Tezi, Marmara Üniversitesi Sosyal Bilimler Enstitüsü, İstanbul.

Emür, S. ve Onsekiz, D. (2007), "Kentsel Yaşam Kalitesi Bileşenleri Arasında Açık ve Yeşil Alanların ÖnemiKayseri/Kocasinan İlçesi Park Alanları Analizi”, Erciyes Üniversitesi Sosyal Bilimler Enstitüsü Dergisi, Sayı.22, 367-396.

Gürbüz, S., Şahin, F. (2016). Sosyal Bilimlerde Araştırma Yöntemleri. Ankara: Seçkin Yayıncılık.

Habitat II. (1996), Türkiye Ulusal Rapor ve Eylem Planı. Birleşmiş̧ Milletler İnsan Yerleşimleri Konferansl, Istanbul.

Kabadayı, H. (2006), "Yaşam Kalitesi ve Kullanıcı Memnuniyetinin Kentsel Tasarımdaki Etkisine Çok Boyutlu Yaklaşım”, Yüksek Lisans Tezi, İstanbul Teknik Üniversitesi Fen Bilimleri Enstitüsü, İstanbul.

Keleș, R. (1998), Kentbilim Terimleri Sözlügü, Ankara: İmge Kitabevi.

Keskin, E. (2010), "Sürdürülebilir Kent Kavramına Farklı Bir Bakış Olarak Yavaş Şehirler (Cittaslow): Seferihisar Örneği", Yüksek Lisans Tezi, Dumlupınar Üniversitesi Sosyal Bilimler Enstitüsü, Kütahya.

Keskin, E. (2012), "Sürdürülebilir Kent Kavramına Farklı Bir Bakış: Yavaş Şehirler (Cittaslow)”, PARADOKS Ekonomi, Sosyoloji ve Politika Dergisi, Sayı.1, 81-99.

Koyuncu, B. (2011), "Kentsel Yaşam Kalitesi Kriterleri: İstanbul Büyükşehir Belediyesi Örneği”, Yüksek Lisans Tezi, Marmara Üniversitesi Sosyal Bilimler Enstitüsü, İstanbul.

Marans, R. (2007). Kentsel Yaşam Kalitesinin Ölçülmesi, Mimarlık Dergisi, 335.

http://www.mimarlikdergisi.com/index.cfm?sayfa=mimarlik\&DergiSayi=53\&RecID=1326, (22.10.2018).

Noll, H.H. (1996), "Social Indicators and Social Reporting: The International Experience. In Canadian Council on Social Development (ed.). Symposium on Measuring the Wellbeing and Social Indicators. Final Report. Ottawa: Canadian Council on Social Development".

Olgun A. (2016), "Yavaș Şehir (Cittaslow): Seferihisar Örneğiyle Ekonomik ve Mali Yapı", Yüksek Lisans Tezi, Karadeniz Teknik Üniversitesi Sosyal Bilimler Enstitüsü, Trabzon.

Özgenç, Ö. (2012), “İdeal Toplum Düzeni Arayışında Kurgulanan Kentsel Planlamalar, Ütopyalar ve Yavaş Şehir Akımı", Yüksek Lisans Tezi, Mimar Sinan Güzel Sanatlar Üniversitesi Fen Bilimleri Enstitüsü, İstanbul.

Sezgin, M., Ünüvar, Ş. (2011), Sürdürülebilirlik ve Șehir Pazarlaması Ekseninde Yavaş Şehir, Konya: Çizgi Kitabevi.

Tekin, C. (2017), "Yavaş Turizm ve Yavaş Turist: Cittaslow Seferihisar'da Karşıllaştırmalı Bir Araştırma”, Yüksek Lisans Tezi, Batman Üniversitesi Sosyal Bilimler Enstitüsü, Batman.

Tıraș, H. (2012), "Sürdürülebilir Kalkınma ve Çevre: Teorik Bir İnceleme”, Sütçü İmam Üniversitesi İktisadi ve İdari Bilimler Fakültesi Dergisi, Sayı.2, 57-73. 
Tosun, E. (2013), “Sürdürülebilir Kentsel Gelişim Sürecinde Kompakt Kent Modelinin Analizi”, Dokuz Eylül Üniversitesi Sosyal Bilimler Enstitüsü Dergisi, Sayı.1, 103-120.

Tosun, E. (2017), "Sürdürülebilirlik Bağlamında Ekolojik Kent Söylemi”, AİBÜ Sosyal Bilimler Enstitüsü Dergisi, Sayı.4, 169-189.

Tunçer, P. (2016), "Sürdürülebilir Kentleşme Politikaları ve Türkiye”, Turkish Studies, International Periodical for The Languages, Literature and History of Turkish or Turkic, Sayl.11/2, 1267-1300.

Türksever, A. Nilay Evcil. (2001), “Türkiye’de Büyük Şehir Alanlarında Yaşam Kalitesinin Değerlendirilmesine Yönelik Bir Yöntem Denemesi”, Doktora Tezi, İstanbul Teknik Üniversitesi Fen Bilimleri Enstitüsü, İstanbul.

Yalçın, A. ve Yalçın, S. (2013), "Sürdürülebilir Yerel Kalkınma İçin Cittaslow Hareketi Bir Model Olabilir mi?”, Sosyal ve Beşeri Bilimler Dergisi, Sayı.1, 32-41.

Yavuzçehre, P. ve Torlak, S. (2006), "Kentsel Yaşam Kalitesi ve Belediyeler: Denizli Karşıyaka Mahallesi Örneği”, Süleyman Demirel Üniversitesi Sosyal Bilimler Enstitüsü Dergisi, Sayı.4, 184-207.

Yıldız, T., H. (2007). Kentsel Yaşam Kalitesi: Kuram, Politika ve Uygulamalar, Mimarlık Dergisi, 335.

http://www.mimarlikdergisi.com/index.cfm?sayfa=mimarlik\&DergiSayi=53\&RecID=1325, (15.10.2018).

Yurtseven, H., Kaya, O., Harman, S. (2010), Yavaş Hareketi, Ankara: Detay Yayıncılık.

\section{İnternet Kaynakçası}

Cittaslow Türkiye: http://cittaslowturkiye.org/, (07-09.10.2018).

Worldometers: http://www.worldometers.info/world-population/, (11.03.2019).

Ekonomik Kalkınma ve İşbirliği Örgütü (OECD): http://stats.oecd.org/Index.aspx?DataSetCode=BLI, (23.10.2018).

TMMOB Mimarlar Odası Ankara Şubesi: http://www.mimarlarodasiankara.org/?id=964, (27.10.2018). 